\title{
CONCURSOS DE RAINHAS: PODER E BELEZA EM CENA
}

\author{
Beauty contests: power and beauty on stage
}

\author{
Adriana Cançado*
}

LOBATO, Mirta Zaida (Org.). Cuando las mujeres reinaban: belleza, virtud y poder en la Argentina del siglo XX. Buenos Aires: Biblos, 2005.

Cuando las mujeres reinaban é um livro organizado por Mirta Zaida Lobato, professora e pesquisadora da Faculdade de Filosofia e Letras da Universidade de Buenos Aires. Os escritos que compõem a coletânea integram investigações sobre práticas trabalhistas argentinas, suas imbricações com a cultura e com as relações de gênero, no decorrer do século XX, com enfoque no período denominado de primeiro peronismo (1945-1955). Em comum, quatro dos cinco estudos apresentam como objetos de pesquisa eventos festivos cujos pontos máximos das comemorações eram os concursos femininos, espaços rituais em que belas mulheres, pertencentes a grupos populares, eram consagradas rainhas, personificando representações identitárias locais e ideais femininos projetados para o período.

O corpus documental utilizado na análise dos concursos constitui-se de fotografias acondicionados em arquivos públicos e privados, imagens e textos publicados em jornais e revistas e entrevistas com mulheres eleitas rainhas nas cerimônias de consagração. Os documentos foram minuciosamente analisados no decorrer da execução de um projeto destinado a reconstruir a memória individual e coletiva de mulheres argentinas. Os trabalhos originados nesse processo analítico confirmam a concepção epistemológica de que as pesquisas sobre as mulheres do passado devem amparar-se na perspectiva interdisciplinar e priorizar fontes consideradas não tradicionais na historiografia, assim como o intercruzamento dessas mesmas fontes. Os estudos que compõem o livro apresentam justamente esse exercício, cruzando entrevistas com fotografias e artigos publicados na imprensa argentina. 
As análises pautam-se em cinco festas que associavam lazer e competição, tornando-se espaços de sociabilidade de heterogêneos grupos sociais onde hierarquias de classe e de gênero eram reproduzidas. Nos jogos representacionais praticados nos concursos, imagens de mulheres trabalhadoras eram desmitificadas, ao mesmo tempo em que valores morais femininos vinculados à virtude, maternidade e abnegação eram reforçados. Assim, papéis sociais tidos como legítimos às mulheres, e também às mulheres belas, eram reproduzidos. As mulheres eleitas rainhas personificavam a esposa, a mãe, a dona de casa, em corpos de mulheres trabalhadoras, pertencentes às classes populares, criando uma idéia de continuidade dos papéis de gênero que diluía as oposições entre espaço doméstico e espaço do trabalho. De outro modo, a participação de jovens e belas mulheres trabalhadoras nos concursos de rainha simbolizava concepções de progresso e desenvolvimento associados com práticas sociais, políticas e econômicas.

Imagens fotográficas, produzidas nas cerimônias de entrega do "Premio a la Virtud", são perscrutadas por Ana Lía Rey e Cecilia Tossounian e as análises resultam no texto "Imágenes de mujeres virtuosas: moralidad, género y poder en la Argentina de entreguerras" (Capítulo I). A cerimônia dos "Premios a la Virtud" era organizada pela centenária instituição "Sociedad de Beneficencia", voltada para atividades assistenciais e dirigida por mulheres das elites.

Para as autoras, essa premiação representava a legitimação de valores morais, baseados no sacrifício e na abnegação, defendidos pelas mulheres das elites e procurados nas práticas cotidianas de mulheres pobres. Anualmente, as organizadoras do evento atribuíam a algumas mulheres a premiação, como recompensa a comportamentos pautados em valores morais defendidos pelas dirigentes da "Sociedad de Beneficencia". A premiação foi instaurada num período de intensas transformações nas relações de gênero e na construção de feminilidades. Nesse período, as mulheres pobres argentinas ingressavam no mercado de trabalho das fábricas e suas condutas eram fortemente vigiadas, pois a ausência de estabilidade econômica conduzia muitas jovens à prostituição. Ao premiar mulheres que, mesmo ao enfrentar problemas econômicos, mantinham valores morais incorruptíveis, as mulheres das elites reforçavam a ordem social dominante e legitimavam seus lugares de moralizadoras da nação. A argumentação das autoras possibilita compreender a circularidade entre valores femininos bur- 
gueses e valores femininos praticados por mulheres pertencentes a grupos populares, assim como apropriações dessas representações como forma de legitimar e naturalizar concepções moralizantes, instituídas por mulheres pertencentes às elites argentinas.

Cecília Belej, Ana Laura Martin e Alina Silveira analisam, no capítulo "Las más bella de los viñedos. Trabajos y producción em los festejos mendocinos (1936-1955)", a festa realizada anualmente ao final da colheita da uva na Província de Mendoza, famosa pela produção de vinho. Organizada pelo poder público, a festa encerrava-se com a eleição da rainha da colheita, que por um ano representaria a produção do vinho e as belezas naturais da região. Jovens mulheres, de origem humilde, pertencentes às classes trabalhadoras rurais, corporificavam valores morais que simbolizavam uma Argentina educada e disciplinada, constituída por trabalhadores esforçados. A beleza das rainhas da colheita exemplificava um conjunto de valores como a moderação, a mesura, a graça, como sinônimo do trabalho produtivo e como reflexo da saúde proporcionada pelo consumo moderado do vinho. Imagens de harmonia e unidade, de exaltação e de controle, de popularidade e de ordem, eram transmitidas de Mendoza para o resto da nação argentina por meio dos valores corporificados nas jovens rainhas eleitas.

A festa de "Primeiro de Mayo" é objeto da análise realizada por Mirta Zaida Lobato, María Damilakou e Lizel Tornay no capítulo intitulado "Las reinas del trabajo bajo el peronismo". A comemoração ao Dia dos Trabalhadores, na Argentina, vinculou-se, por anos, à mobilização popular para a libertação de Domingos Perón, em agosto de 1945, da prisão. A festividade reunia trabalhadores e trabalhadoras, nas ruas de Buenos Aires, e a eleição da rainha integrava um evento maior, formado por apresentações artísticas e desfiles de carroças decoradas. As candidatas ao título de rainha do trabalho representavam sindicatos ou atividades produtivas e eram selecionadas em localidades diversas a fim de disputarem a etapa final, em Buenos Aires, num espetáculo que contava com a participação de Domingos e Eva Perón. Pertencentes a famílias modestas e de trabalhadores, as jovens representavam, uma vez mais, o trabalho digno e beleza, desmitificando imagens anteriores que associavam o trabalho à supressão da beleza feminina. Desse modo, as jovens dignificavam o trabalho feminino através da exibição da beleza. De outro modo, reforçava ideais de casamento e maternidade ao anunciarem, em entrevistas, ser esse o sonho de suas vidas. De certa maneira, essas mulheres 
atualizavam a história de Eva Perón, que de jovem humilde se transformou na primeira dama da Argentina e, como recriação dessa pessoa, as rainhas do trabalho amavam suas localidades, Perón e os pobres, constituindo-se em símbolo da ligação existente entre Perón e os grupos populares argentinos. A eleição das rainhas, o ideal de beleza e a ideologia peronista estavam embasados na noção de harmonia difundida durante o período. As rainhas representavam a beleza, o espírito do povo argentino e todas as mulheres que trabalhavam. Assim, as qualidades das rainhas - trabalhadoras e belas - estendiam-se a todas as mulheres do país.

No capítulo "Reinas y campesinas: las 'hijas de los colonos' em escena", María José Billorou e Ana María Rodríguez investigam as três primeiras edições da festa regional do trigo (1946, 1948, 1949), ocorridas no território La Pampa. Baseadas em fotografias publicadas na imprensa, arquivadas pela entidade organizadora e por particulares. As autoras estudam as festividades entendendo-as como uma fase de institucionalização do evento coincidente com os primeiros governos de Domingo Perón e como cerimônias que objetivavam demonstrar as possibilidades de provincialização do território, objetivo das autoridades locais. Compreendida como espaço de sociabilidade, a festa contava com exposição industrial e agropecuária, torneios esportivos, atividades infantis, palestras e a realização do baile para homenagear a rainha. Desse modo, a festa constituía-se num espaço onde se mesclavam cultura, lazer e política. Além disso, os laços sociais pretensamente instituídos pelo congraçamento entre os vários grupos sociais concretizavam a associação entre a atividade produtiva e a identidade local, necessárias para o processo de provincialização. A eleição da rainha investia-se de uma centralidade em que materializavam-se o progresso e o desenvolvimento alcançados com a produção agrícola na região, argumentos recorrentemente usados a favor da provincialização de La Pampa, conquistada em 1951. As rainhas eleitas representavam a mulher do campo - mães, esposas e companheiras do homem na labuta agrícola -, símbolo da força mantenedora das famílias no meio rural, pretensão do governo Perón. A moralidade das jovens era conclamada nos discursos e simbolizada como uma forma de controle e preservação dos papéis tradicionais femininos. Desse modo, a festa foi também um meio de consolidar e difundir uma identidade de gênero inspirada na mulher rural, que em seu fazer doméstico contribuía para manter a família no campo, 
para reforçar padrões de beleza e um modelo de feminilidade amparado em papéis femininos tradicionais. A festa e a exaltação da agricultura, da beleza feminina e da moralidade articuladas em torno de ideais de progresso e desenvolvimento revelou-se um espaço para representações e reprodução de identidades regionais e de gênero.

Edda Lía Crespo, no capítulo "Madres, esposas, reinas... Petróleo, mujeres y nacionalismo em Comodoro Rivadavia durante los años del primer peronismo", estuda a Festa Nacional do Petróleo, comemorada entre os anos de 1947 a 1984 e organizada para festejar o desenvolvimento da região de Comodoro Rivadavia, capital do governo militar, lotado no território Del Chubut. Criado para homenagear as atividades petrolíferas, o evento vinculou beleza feminina e ação política. Festa popular, onde a coroação das rainhas ocupava lugar de destaque, o evento possuía uma particularidade: a presença da mãe de Domingos Perón, moradora da região, que consagrava a rainha eleita com um beijo na face. Essa presença tinha um forte significado simbólico, pois exaltava o parentesco filial, estabelecia vínculos entre a nação peronista e as populações do território. As candidatas ao título eram jovens trabalhadoras para quem a presença e o beijo da mãe do presidente argentino representaria a revalorização da maternidade, lembrando a todas as demais mulheres de que não se poderia fugir desse destino, "naturalmente" feminino.

A constante associação entre a representação da mulher trabalhadora e os poderes econômicos e políticos, que permeia todos os estudos, indicam que, no período em que o(a) trabalhador(a) argentino(a) foi investido(a) de simbologias que o(s) valorizava(m) diante e a partir do poder político, os concursos de rainhas converteram-se em espaços de reconstrução e reafirmação identitárias. Essa reconstrução baseava-se em novos modelos de feminilidade - que associavam as mulheres ao espaço do trabalho - sem, no entanto, perder o potencial de reprodução de ideais tradicionais pensados para o feminino, como a responsabilidade pela manutenção de valores morais apoiados na valorização do casamento e da maternidade.

Assim, as análises que compõem o livro Cuando las mujeres reinaban contribuem para a relativização de posturas que afirmam serem os concursos femininos frívolos e óbvios para serem investigados ou outras ainda que acusem esses eventos como espaços que convertem mulheres em objetos para exposição ou para consumo. As autoras inspiram 
possibilidades teórico-metodológicas para o estudo de concursos femininos, cujas abordagens amparam-se em concepções de poder - econômico e político - e relações com características idealizadas para o feminino, como a beleza, a maternidade e o casamento, possibilitando a queda do véu que ainda insiste em encobrir esses eventos como sérios objetos de pesquisa historiográfica. Complementarmente, é possível afirmar que concursos de rainhas são eventos historicamente datados, cujos significados são múltiplos e referem-se às culturas onde ocorrem e que os legitimam, reconhecendo-os como espaços válidos para práticas sociais. Nessa perspectiva, os concursos de rainhas, que não são exclusivamente concursos de beleza, pois integram outras representações como identidade, ideais de feminilidade, política e economia, são ricos espaços para o estudo das sociedades onde ocorrem, assim como as simbologias construídas por essas sociedades para expressar o conhecimento que possuem de si mesmas, pelos quais também pretendem ser identificadas. 